\title{
PELATIHAN MANAJEMEN KEUANGAN BAGI PELAKU UMKM SEBAGAI UPAYA PENGUATAN UMKM JABAR JUARA NAIK KELAS
}

\author{
Haris Fauzi \\ Universitas Majalengka, Indonesia \\ harisfauzi@unma.ac.id
}

\begin{abstract}
Management is a set of activities in the form of planning and decision making, organizing, directing and controlling directed towards organizational resources (human, financial, physical equipment and information) with the aim of achieving organizational goals in an efficient and effective manner (Stoner, 2009). Management functions that must be carried out are the planning function, the organizing function, the control function and the supervisory function. Many SMES do manage their business without having a knowledge base or skills regarding good business management and financial management. Not infrequently the business is only carried out by relying on instinct and experience alone. The implementation of Community Service activities is carried out using lecture, tutorial, and discussion methods. Based on the data in the field, the training participants really understood the explanation of the material presented. This is evidenced by a variety of questions asked and discussions.
\end{abstract}

Keywords: training, financial management, strengthening MSME.

\begin{abstract}
Abstrak
Manajemen adalah seperangkat kegiatan berupa perencanaan dan pengambilan keputusan, pengorganisasian, pengarahan dan pengendalian yang diarahkan kepada sumberdaya organisasi (manusia, finansial, peralatan fisik dan informasi) dengan tujuan untuk mencapai tujuan organisasi dengan cara berdaya guna dan berhasil guna (Stoner, 2009). Fungsi-fungsi manajemen yang harus dilakukan adalah fungsi perencanaan, fungsi pengorganisasian, fungsi pengendalian serta fungsi pengawasan. Banyak pelaku UMKM yang mengelola usahanya tanpa memiliki dasar pengetahuan maupun ketrampilan mengenai manajemen usaha dan manajemen keuangan yang baik. Tidak jarang usaha hanya dijalankan dengan mengandalkan insting dan pengalaman saja.Pelaksanaan kegiatan Pengabdian Pada Masyarakat ini dilakukan dengan menggunakan metode ceramah, tutorial, dan diskusi. Berdasarkan data di lapangan para peserta kegiatan pelatihan sangat memahami penjelasan materi yang disampaikan. Hal ini dibuktikan dengan berbagai macam pertanyaan yang diajukan serta diskusi.
\end{abstract}

Kata Kunci: pelatihan, manajemen keuangan, penguatan UMKM.

Submitted: $2020-06-26$

Revised: 2020-07-24

Accepted: $2020-07-26$

\section{Pendahuluan}

UMKM ( Usaha Mikro Kecil dan Menengah) merupakan penyangga perekonomian Indonesia saat ini. Hal ini ditunjukkan dengan kontribusi sektor UMKM pada PDB (Produk Domestik Bruto) tahun 2019 yang mencapai 65 persen atau sekitar 2.394,5 triliun. Dengan jumlah unit usaha yang mencapai 55 juta unit pada tahun 2019, sektor UMKM mampu menyediakan lapangan kerja bagi 101 juta orang atau sekitar 99 persen dari seluruh angkatan kerja Indonesia. UMKM telah menjadi penopang laju pertumbuhan ekonomi, penggerak sektor riil dan penyerap tenaga kerja yang cukup signifikan melalui pengembangan kewirausahaan. 
UMKM juga terbukti paling tangguh dalam menghadapi krisis moneter tahun 19971998. Sebagian besar UMKM mampu bertahan dalam krisis ekonomi antara lain karena penggunaan bahan baku, tenaga kerja dan orientasi pasar yang bersifat lokal. Pelaku UMKM pun semakin bertambah jumlahnya pasca krisis. Beberapa faktor yang dianggap menjadi penyebab terjadinya peningkatan jumlah pelaku UMKM tersebut antara lain:

1. Pada umumnya produk UMKM merupakan barang konsumsi dengan elastisitas permintaan terhadap pendapatan yang rendah sehingga perubahan tingkat pendapatan akibat krisis ekonomi tidak banyak berpengaruh terhadap konsumsi barang yang dihasilkan.

2. Sebagian besar UMKM tidak menggunakan kredit modal dari bank sehingga pada saat krisis ekonomi mereka terhindar dari beban bunga tinggi akibat peningkatan suku bunga kredit.

3. Bisa dikatakan hampir tidak ada hambatan untuk keluar masuk dalam industri yang digeluti oleh UMKM sehingga semua orang bisa menjadi pelaku UMKM.

4. Banyaknya tenaga pengangguran akibat pemutusan hubungan kerja dari sektor formal yang kemudian memulai usaha baru atau bergabung di sektor UMKM. (Pratomo (2004) seperti dikutip di www.pajak.go.id)

Meskipun jumlah pelaku UMKM cukup banyak dan memberikan kontribusi yang besar bagi perekonomian nasional, namun sebagian besar UMKM mengalami kesulitan dalam mengembangkan usahanya. Secara umum, persoalan yang dihadapi oleh UMKM meliputi akses permodalan, pemasaran, manajemen usaha dan keuangan, aspek legal dan perpajakan.

Banyak pelaku UMKM yang mengelola usahanya tanpa memiliki dasar pengetahuan maupun ketrampilan mengenai manajemen usaha dan manajemen keuangan yang baik. Tidak jarang usaha hanya dijalankan dengan mengandalkan insting dan pengalaman saja. Aspek-aspek manajemen usaha yang meliputi perencanaan usaha, pengorganisasian, implementasi, dan pengendalian usaha menjadi sesuatu yang jarang diperhatikan padahal hal tersebut sangat penting dalam membangun dan mengembangkan usaha. Demikian pula dengan pengelolaan keuangan usaha; banyak UMKM yang tidak melakukan pembukuan formal terhadap usahanya. Perhitungan laba sering dilakukan dengan sederhana tanpa melakukan analisis biaya secara memadai. Misalnya usaha yang menggunakan bahan baku/bahan mentah yang diambil dari lahan sendiri dan melibatkan anggota keluarga sendiri, biasanya tidak memasukkan komponen tersebut sebagai biaya bahan baku dan biaya tenaga kerja dalam penghitungan formal biaya.

Kelompok UMKM merupakan golongan usia produktif yang berpotensi besar menjadi penggerak perekonomian Indonesia. Semangat berwirausaha yang didukung dengan pengetahuan dan ketrampilan teknis diharapkan akan memberikan bekal dalam memulai dan mengembangkan usaha.

Hal tersebut menunjukkan adanya potensi kewirausahaan dan pengembangan UMKM yang cukup besar. Meskipun demikian, UMKM yang ada belum berkembang secara optimal karena masih kurangnya pengetahuan mengenai manajemen usaha dan manajemen keuangan usaha. Hal ini dimungkinkan karena kurangnya pemahaman terhadap pentingnya manajemen usaha dan keuangan serta kesibukan 
oleh aktivitas bisnis demikian pula bagi pemuda/pemudi yang masih sekolah/kuliah, kegiatan wirausaha melalui UMKM masih dianggap sebagai sesuatu yang sulit dikarenakan kurangnya bekal pengetahuan dan ketrampilan teknis untuk menjalankannya.

Manajemen keuangan yang baik akan memberikan manfaat besar bagi UMKM. Dengan melakukan pencatatan keuangan dengan tertib, UMKM dapat mengetahui kondisi keuangan sekaligus perkembangan usahanya. Kondisi aset, utang, modal, arus kas, serta fluktuasi laba UMKM dapat diketahui dengan mudah sehingga membantu pelaku UMKM dalam membuat keputusan bisnis penting, seperti pembelian aset baru dan rencana pengembangan usaha. Manajemen keuangan yang baik juga akan memperbaiki aspek pengendalian usaha, dimana pelaku UMKM dapat mengetahui apakah rencana keuangannya tercapai atau tidak serta membantu mencari tahu penyebabnya.begitu juga dengan aspek permodalan, dengan memiliki administrasi keuangan yang tertib akan memudahkan UMKM dalam pengajuan pinjaman modal kepada pihak bank atau lembaga keuangan lainnya.

Berdasarkan uraian yang telah dijelaskan sebelumnya, perlu diadakan pelatihan manajemen keuangan bagi pelaku UMKM di Kabupaten Majalengka. Dengan diadakannya pelatihan manajemen keuangan tersebut diharapkan akan mampu memberikan bekal pengetahuan yang memadai dan selanjutnya dapat diimplementasikan ke dalam usaha nyata sehingga pada akhirnya mampu membantu pengembangan UMKM untuk mewujudkan ekonomi Indonesia yang lebih kuat di masa mendatang.

1. Pengelolaan Keuangan UMKM

Phobi Kevin dalam Baskoro (2014) menyampaikan lima tips dalam pengelolaan keuangan usaha, antara lain:

a. Perlunya pemisahan antara keuangan usaha dan keuangan pribadi;

b. Menentukan besarnya persentase keuangan yang akan untuk kebutuhan usaha;

c. Melakukan pencatatan keuangan (pembukuan) secara tertib untuk mengontrol semua transaksi keuangan, baik itu pemasukan maupun pengeluaran, serta utang dan piutang;

d. Mengurangi risiko dari utang usaha;

e. Mengendalikan kelancaran arus kas usaha.

Manajemen keuangan merupakan salah satu aspek penting dalam usaha, namun sering diabaikan, baik karena minimnya pengetahuan pelaku usaha maupun karena kesibukan aktivitas operasional bisnis sehari-hari. Sebagai contoh, mencampur keuangan pribadi/rumah tangga dengan keuangan usaha akan menyulitkan pengusaha dalam memonitor kemajuan usahanya. Begitu pula pengaturan arus kas diperlukan pengusaha untuk memastikan ketersediaan kas guna membayar pembelian bahan baku ke supplier serta membayar utang jangka pendek yang jatuh tempo.

2. Laporan Keuangan UMKM

Laporan keuangan yang diperlukan oleh UMKM tentunya berbeda dengan laporan keuangan untuk perusahaan besar. Melihat kompleksitas dan ukuran usaha yang lebih kecil, laporan keuangan yang perlu disusun menjadi lebih sederhana. Dengan demikian pengusaha kecil tidak perlu terlalu takut membayangkan rumitnya 
penerapan pencatatan keuangan dan penyusunan laporan keuangan bagi usahanya. berikut ini adalah jenis laporan keuangan yang bisa disiapkan oleh pelaku UMKM:

a. Laporan rugi laba

Laporan rugi laba digunakan untuk mengetahui laba.rugi usaha melalui pencatatan pemasukan (berasal dari penjualan barang atau jasa) dan pencatatan pengeluaran (biaya-biaya operasional dan non-operasional usaha). Laba/rugi menunjukkan tingkat keberhasilan usaha yang selanjutnya dapat digunakan untuk mengembangkan usaha tersebut.

b. Laporan perubahan modal

Laporan ini menunjukkan perubahan modal yang dimiliki oleh pemilik sebelum dan sesudah kegiatan usaha pada suatu periode, yaitu sesuai denganjumlah laba/rugi yang dihasilkan dalam periode yang bersangkutan.

c. Neraca

Neraca menunjukkan posisi keuangan usaha, yaitu menunjukkan besarnya asset, hutang dan modal usaha.

d. Laporan arus kas

Laporan arus kas memperlihatkan aliran kas keluar dan masuk pada berbagai kegiatan operasional, investasi, dan pembiayaan usaha. Dengan mengetahui arus kas ini, manajemen UMKM akan mengetahui jumlah dan waktu untuk mendapatkan kas dari penjualan dan penagihan piutang maupun kas keluar dari pembayaran biaya-biaya operasional dan hutang.

\section{Metode}

Khalayak sasaran yang dipilih adalah para Pelaku UMKM Jabar Juara sebanyak 15 orang. Mereka dipilih dengan pertimbangan bahwa Pelaku UMKM Jabar Juara merupakan golongan usia produktif yang memiliki kekuatan penggerak. Dengan pelatihan yang akan diberikan, diharapkan dapat memberikan bekal pengetahuan dan ketrampilan wirausaha, khususnya dalam hal manajemen keuangan, serta mendorong pengembangan UMKM untuk memperkuat basis perekonomian masyarakat. Lebih lanjut, pengetahuan dan ketrampilan yang diperoleh diharapkan dapat disampaikan ke masyarakat sekitarnya sehingga dapat memberikan manfaat yang lebih besar.

Pelaksanaan kegiatan Pengabdian Pada Masyarakat ini dilakukan dengan menggunakan metode ceramah, tutorial, dan diskusi. Adapun tahapan pelaksanaan kegiatan pengabdian ini adalah sebagai berikut:

1. Langkah 1 (Metode Ceramah):

Peserta diberikan wawasan mengenai pentingnya manajemen keuangan dalam memulai maupun menjalankan usaha. Langkah pertama diselenggarakan melalui metode ceramah selama 1,5 jam.

2. Langkah 2 (Metode Tutorial):

Peserta pelatihan diberikan materi tentang penyusunan laporan keuangan, meliputi: laporan laba rugi, laporan perubahan modal, neraca serta laporan arus kas. Materi ini disampaikan dalam bentuk tutorial disertai dengan latihan/studi kasus. Langkah kedua diselenggarakan selama 5 jam. 
3. Langkah 3 (Metode Diskusi):

Peserta pelatihan diberikan kesempatan untuk mendiskusikan permasalahan yang berkaitan dengan usaha yang sudah mereka jalani ataupun hal-hal yang ingin mereka tanyakan untuk memulai usaha. Langkah ketiga diselenggarakan selama 1,5 jam.

Disamping langkah 1, 2, dan 3 di atas, akan dilakukan kegiatan pendampingan untuk menyusun laporan keuangan usaha selama 8 jam dengan jadwal menyesuaikan peserta khalayak sasaran sehingga jumlah jam pengabdian masyarakat terpenuhi 16 jam.

\section{Hasil dan Pembahasan}

Kegiatan pengabdian kepada masyarakat dengan mengangkat tema "Pelatihan Manajemen Keuangan Bagi Pelaku UMKM Sebagai Upaya Penguatan UMKM Jabar Juara Naik Kelas" dilaksanakan oleh pengabdi dari Program Studi Manajemen, Fakultas Ekonomika dan Bisnis Universitas Majalengka di Desa Ciomas Kecamatan Sukahaji Kabupaten Majalengka tepatnya di rumah pengusaha batik ibu Juju Juariyah. Kegiatan pelatihan ini diikuti oleh 15 orang peserta yang terdiri dari pelaku UMKM. Peserta yang mengikuti kegiatan ini wajib mengisi daftar hadir yang telah disediakan oleh pengabdi.

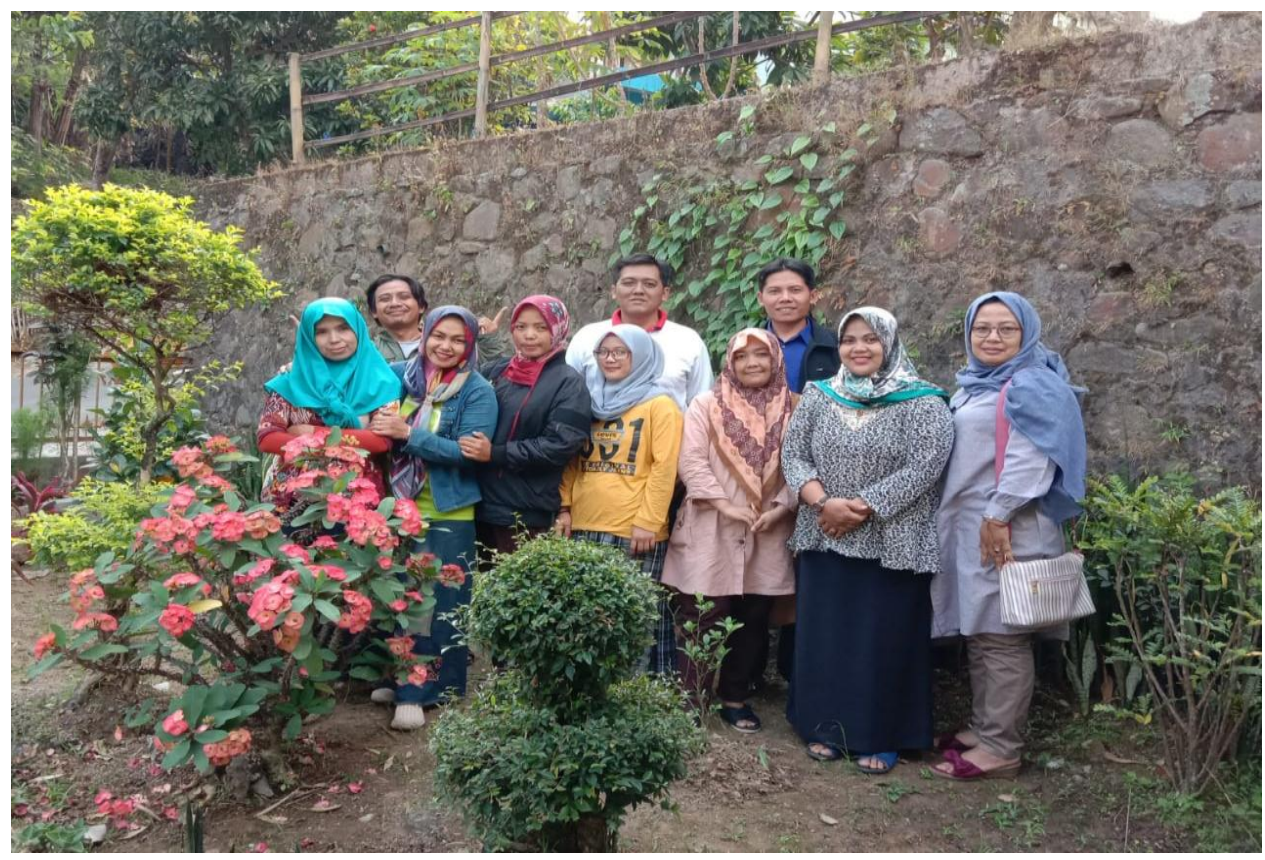

Gambar 1. Sebelum Pelatihan

Bagian ini mengemukakan gambaran umum lokasi dan data yang diperoleh selama pelaksanaan kegiatan pengabdian kepada masyarakat (PKM). Kegiatan ini dilakukan Dengan menggunakan metode ceramah, Tanya jawab dan diskusi. Kegiatan ini merupakan pengabdian dalam rangka menumbuhkan minat dan kesadaran para pelaku UMKM Jabar Juara di lingkungan Kabupaten Majalengka untuk dapat memahami, menghitung dan menyusun keuangan secara benar dan transparan serta bertanggung 
jawab dalam upaya meningkatkan Omset pelaku UMKM Jabar Juara di lingkungan Kabupaten Majalengka.

Berdasarkan hasil survey dan konsultasi dengan Tuan rumah di Desa Ciomas, maka pada tanggal 5 Juni 2020 telah dilaksanakan kegiatan sosialisasi dan pelatihan manajemen keuangan laporan keuangan bagi pelaku UMKM Jabar Juara, dalam meningkatkan pemahaman para pelaku UMKM dalam membuat laporan keuangan usahanya.
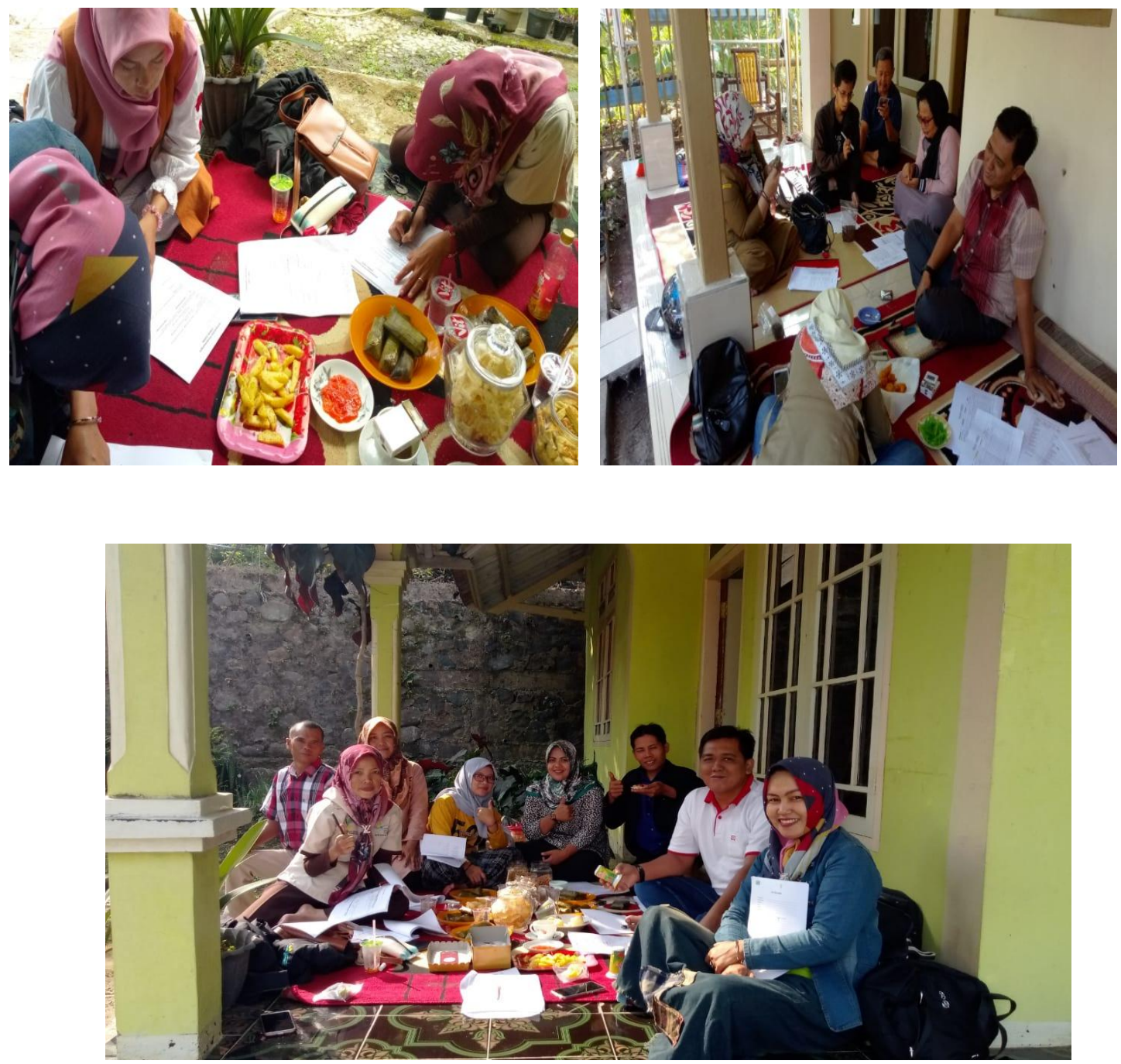

Gambar 2. Ceramah dan Tutorial Pembukuan Usaha

Peserta pelatihan pada tahap awal (sesi I), diberikan materi tentang laporan keuangan UMKM. Peserta pada tahap kedua (sesi II) diberikan pelatihan Penyusunan laporan keuangan Neraca dan Laba Rugi Singkat Sesuai contoh kasus. Setelah itu para peserta diajak berdialog dengan tanya jawab menyangkut materi yang telah disampaikan. Sedangkan hasil evaluasi yang telah dilakukan untuk mengukur tingkat keberhasilan program kegiatan pengabdian ini, dapat dijabarkan sebagai berikut:

a. Meningkatnya Pengetahuan serta minat dari para pelaku UMKM di lingkungan Kabupaten Majalengka yang masuk daftar UMKM Jabar Juara tentang materi laporan keuangan. 
b. Tingkat pengetahuan dan pemahaman para pelaku UMKM diukur dengan partisipasi yang berkembang dalam tanya jawab dan praktek ilustrasi pelatihan perhitungan contoh soal kasus penyusunan laporan keuangan.

Berdasarkan data di lapangan nampak bahwa para peserta kegiatan pelatihan sangat memahami penjelasan materi yang disampaikan. Hal ini dibuktikan dengan berbagai macam pertanyaan yang diajukan serta diskusi.

\section{Respon Peseta Terhadap Materi Pelatihan}

Persentase respon peserta terhadap materi pelatihan menunjukkan sebagian besar Faham dengan materi pelatihan sebesar $53 \%$, bahkan ada responden yang memilih sangat faham sebesar $33 \%$, sisanya responden menjawab kurang faham $20 \%$, dan tidak faham $0 \%$. Persentase respon peserta terhadap materi dapat digambarkan pada grafik berikut.

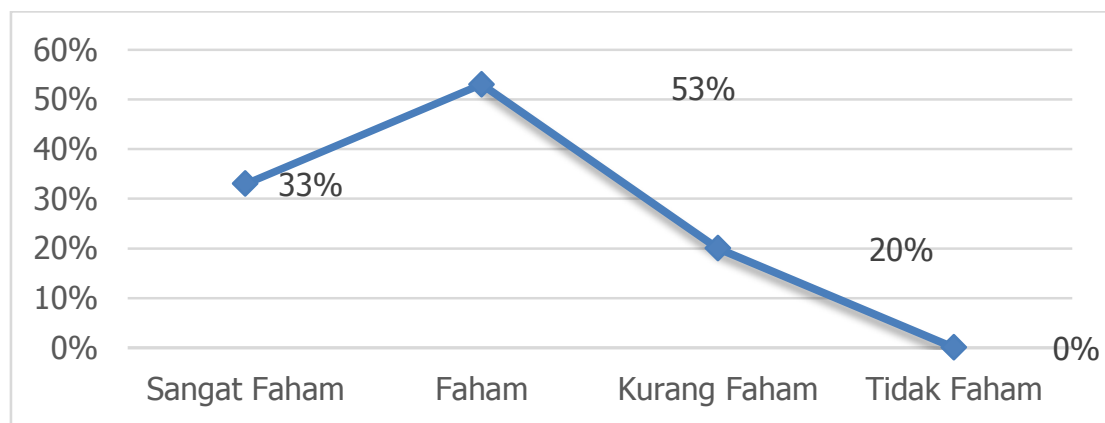

Gambar 3. Respon Peserta Terhadap Materi Pelatihan

Grafik pada gambar di atas menunjukkan bahwa respon peserta yang mengerti terhadap materi pelatihan mempunyai respon positif yang karena banyak memilih jawaban faham dan sangat faham. Berdasarkan persentasi responden yang tinggi pada alternatif jawaban faham dan sangat faham maka dapat disimpulkan bahwa materi yang dipaparkan saat pelatihan berkategori sudah sangat baik.

\section{Respon Peserta Terhadap Metode Pelatihan}

Metode pelatihan yang digunakan pada pelatihan ini adalah ceramah dan praktik. Respon peserta terhadap metode pelatihan yang digunakan sebagian besar menjawab sangat setuju sebesar $55 \%$, responden yang memilih alternatif jawaban setuju sebesar40\%, sedangkan sisanya memilih alternatif jawaban kurang setuju 4\% dan tidak setuju $2 \%$. Persentase respon peserta terhadap metode pelatihan dapat digambarkan pada grafik berikut. 


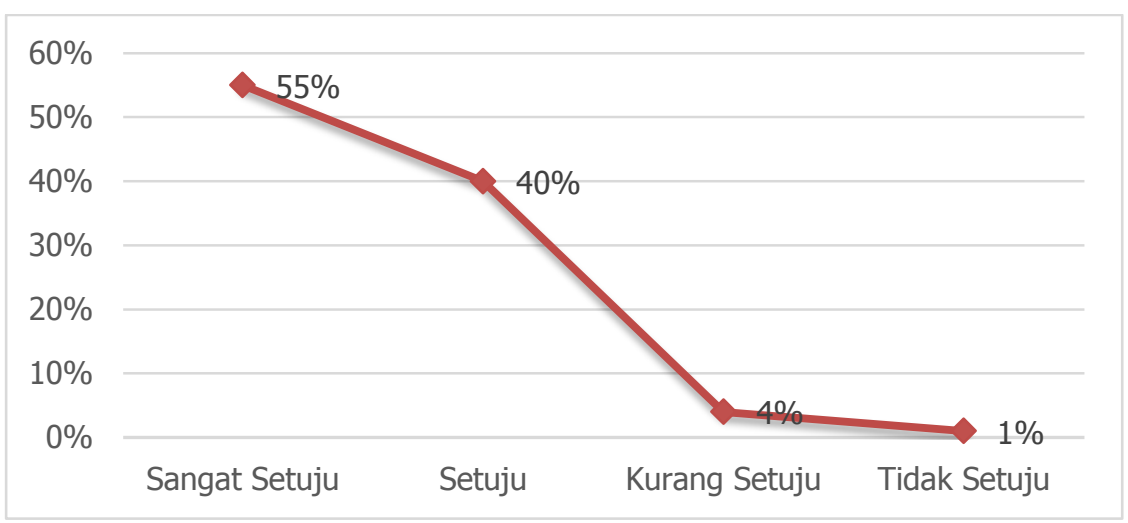

Gambar 4. Respon Peserta Terhadap Metode Pelatihan

Grafik pada gambar di atas menunjukkan bahwa respon peserta terhadap metode pelatihan mempunyai respon positif karena banyak yang memilih jawaban setuju dan sangat setuju. Berdasarkan persentasi responden yang tinggi pada alternatif jawaban sangat setuju dan setuju, maka dapat disimpulkan bahwa metode pelatihan yang digunakan saat pelatihan berkategori sudah sangat baik.

\section{Kesimpulan}

1. Peserta pelaku UMKM di lingkungan Kabupaten Majalengka yang masuk daftar UMKM Jabar Juara memiliki kemampuan menyusun laporan keuangan usaha.

2. Hasil kegiatan pelatihan ini sangat bermanfaat bagi para pelaku UMKM di lingkungan Kabupaten Majalengka yang masuk daftar UMKM Jabar Juara untuk dapat menyusun dan menghitung atau me manajemen laporan keuangan secara baik dan benar serta dapat dipertanggungjawabkan.

3. Mengingat pelatihan manajemen laporan keuangan UMKM ini ini sangat penting bagi para pelaku UMKM, maka disarankan kegiatan ini disosialiasikan dan dapat berkelanjutan serta membuahkan hasil dari minat yang dimiliki oleh para peserta dan masyarakat. guna mendukung program pemerintah desa untuk menjadi desa mandiri dan maju demi kesejahteraan rakyat.

4. Antusias para peserta sangat tercermin dari keseriusan dalam mengajukan berbagai macam pertanyaan, diskusi dan memahami ilusrasi soal praktek.

\section{Daftar Pustaka}

Eugene F. Brigham and Joel F. Houston, (2012). Dasar-dasar Manajemen Keuangan (Terjemahan). Jakarta; Salemba Empat.

Kasmir. (2011). Analisis Laporan Keuangan. Jakarta: PT Raja Grafindo Persada.

Mambula, C. (2002). "Perceptions of SME growth constraints in Nigeria". Journal of Small Business Management: 40(1): 58-65.

Stoner, James A.F., Daniel R. Gilbert, R. Edward Freeman. (2009). Management. $6^{\text {th }}$ Edition. New York: Pearson. 
Suryana. (2004). Modul 20 Kewirausahaan SMK: Evaluasi dan Pengembangan Usaha. Jakarta: Direktorat Pendidikan Menengah Kejuruan Direktorat Jenderal Pendidikan Dasar dan Menengah Departemen Pendidikan Nasional

Suryana. (2011). Kewirausahaan Pedoman Praktis: Kiat dan Proses Menuju Sukses. Jakarta: Salemba Empat. 